\section{Intestinal Parasites, Malaria and Anemia among School Children in Some Flood Affected Areas of Ogbaru Local Government Anambra State, Nigeria}

\section{Abstract}

An epidemiological study was carried out on school children in some flood affected areas of Ogbaru local government Anambra state Nigeria to assess their health and environment after the 2011/2012 flood. Four hundred and eighty primary school children were examined for intestinal parasite, malaria parasite and anaemia. Formol acetate concentration method was used to analyse the stool samples for intestinal parasites. Giemsia's staining technique was used for malaria parasite test, while Haematocrit packed cell volume capillary method and cyanmethaemoglobin method were used to screen for anaemia. Fifty two point five $(52.5 \%)$ percent were infected with one or more of the intestinal parasites. Eighty six point four six percent $(86.46 \%)$ were infected with malaria parasite, while $55.21 \%$ were anaemic (hemoglobin $<11 \mathrm{~g} / \mathrm{dl}$ ). Ascaris lumbricoides was the highest $(29.20 \%)$ intestinal parasites obtained while Hymenolepis nana was least (2.35\%). The highest rate of intestinal parasite infection was seen in the age group $10-13$ years $(52.54 \%)$ and the least was from $14-17$ years $(49.02 \%)$. Intestinal parasites were more in females $(51.29 \%)$ than in males $(48.08 \%)$. The highest rate of infection with malaria parasite was seen among the ages of $6-9$ years $(89.83 \%)$ while $10-13$ years and $14-17$ years had a prevalence of $85.17 \%$ and $85.62 \%$ respectively. Malaria infection was more prevalent in males (45.83\%) than females (40.63\%). The highest prevalence of anaemia was seen between the ages of 10 $13(57.77 \%)$ and the least $14-17$ (52.29\%). Forty seven point five percent of the children had both malaria parasite and anaemia. There was significant association between PCV of malaria infected children and non infected children $(p<0.05)$. These findings suggest that this area has some major public health challenges therefore the need for adequate measures to remedy the situation and avoid epidemics.

Keywords: Health assessment; School children; Flood affected areas; Ogbaru Local Government Anambra State

\section{Ogalue Uchenna $\mathbf{M}^{1 *}$, Ekejindu Ifeoma $\mathbf{M}^{1}$, Ochiabuto OMTB ${ }^{1}$, Obi MC', Obeagu Emmanuell ${ }^{2}$ and Ekelozie Ifeoma $\mathbf{S}^{1}$}

*Corresponding author:

Ogalue Uchenna M

” emmanuelobeagu@yahoo.com

Department of Medical Laboratory Science, Nnamdi Azikiwe University, Nnewi Campus, Anambra State, Nigeria.

Tel: +2348037579108

Citation: Uchenna MO, Ifeoma ME, Ochiabuto OMTB, Obi MC, Emmanuell O, et al. (2018) Intestinal Parasites, Malaria and Anemia among School Children in Some Flood Affected Areas of Ogbaru Local Government Anambra State, Nigeria. Arch Clin Microbiol. Vol.9 No.2:80

\section{Introduction}

Floods are the most common natural disaster in both developed and developing countries, and they are occasionally of devastating impact. Their impacts on health vary between populations for reasons relating to population vulnerability and type of flood event. There is potential for increased faecal-oral transmission of disease, especially in areas where the population does not have access to clean water and sanitation. Such diseases include, nonspecific diarrhoea [1], poliomyelitis, rotavirus, typhoid and paratyphoid, cholera, dysentery [2].

Intestinal parasites account for one of the major faecal orally transmitted diseases which are public health problem worldwide. It is estimated that 3.5 billion people are infected by intestinal parasites and 350 million fall ill due to these organisms [3]. At highest risk of morbidity are pre-school, school-age children and pregnant women [4]. Ascaris lumbricoides, Trichuris trichiura, the 
blood-feeding hookworms Ancylostoma duodenale and Necator americanus, which cause ankylostomiasis and Strongyloidies stercoralis is estimated to have infected 1.2 billion, 800 million, and 740 million people respectively worldwide [5]. Worldwide, 320 million school-age children are infected with $A$. lumbricoides [6]. The high incidence of intestinal parasite has been attributed to a number of factors from unhygienic habits, contaminated food and water to poor sanitary conditions [7].

It is an important cause of morbidity in school age children who harbor the highest intensity of worm infestation, living in conditions of poor sanitation, and their impact on morbidity and mortality is more severe in malnourished populations [8]. Also $68.2 \%$ prevalence rate of intestinal helminthes from stool samples of children 0-17 years was reported from Ibadan [9]. Ova of helminths can also be isolated from the underneath of fingernails [4] and on the surface of Nigerian currency [10].

Anaemia is a major health problem worldwide. According to the World Health Organisation two billion people suffer from anaemia in the world [11] and common among children as a result of nutrition deficiencies, parasitic infections and haemoglobinopathies [12]. Iron deficiency anaemia accounts for most of the anaemia that occurs due to parasitic infections. In the tropics, parasitic infections such as hookworm, schistosomiasis and malaria are predictors for anaemia [12-14]. The contribution of single parasitic infections on the risk of anaemia in schoolchildren is well known, with risk correlated with infection intensity [15].

With the recent flooding, the people of Ogbaru local government area of Anambra state are faced with so many challenges such as poor sanitary system; overflowing of toilets, poor drainage etc. These have affected their lives negatively. This study tends to find out the prevalence of intestinal parasite, malaria parasite and anaemia amongst the children in the environment given these recent challenges (Tables 1-4).

\section{Aims}

This study is designated to determine the prevalence of malaria parasite, intestinal parasites and anaemia among primary school children in Ogbaru LGA, ascertain the potability of their drinking water and determine the prevalence of pathogenic fungi in their classrooms.

\section{Materials and Methods}

\section{Study area}

The study was done in Ogbaru Local Government Area in Anambra State south-eastern Nigeria.

\section{Study population}

The study population was primary school children from nine towns in Ogbaru LGA who were present during the study period. Not more than two primary schools from each community within Ogbaru LGA were selected with at least 32 children all within 6-17 years that fulfilled the inclusion criteria, in all 480 children.

\section{Sampling technique}

Pupils were selected randomly after volunteering based on age and sex. Age range of 6-17 from both sex consisted the number of children from primary [1-6].

\section{Ethical considerations}

Approval was sort from Anambra State Universal Basic Education Board (ASUBEB), The consent of Ogbaru Local Government Educational Secretary, school authorities, and ethical clearance from the Faculty of Health Science and Technology, Nnamdi Azikiwe University, Nnewi campus was also obtained. Verbal and written informed consent was sought from all eligible individuals and from their parents.

The investigation was carried out at the Department of Medical Laboratory Science, Nnamdi Azikiwe University Nnewi Campus (Tables 5-7).

Table 1 Prevalence of intestinal parasites from school children in ogbaru lga.

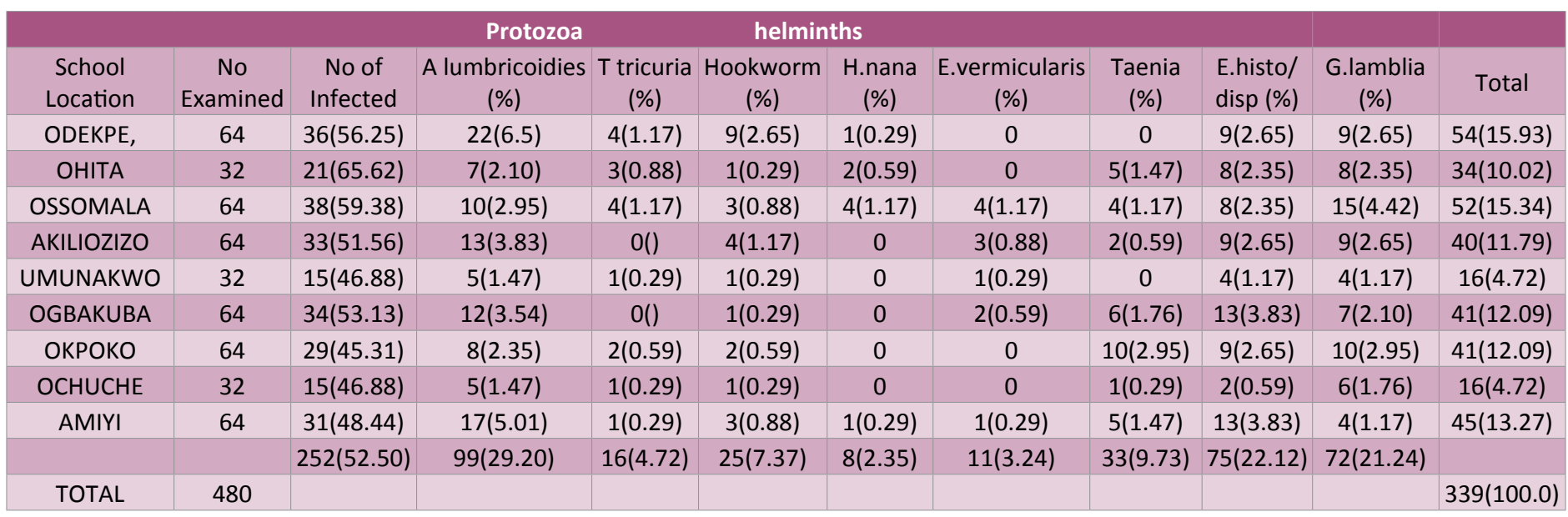


Table 2 Sex distribution of the intestinal parasites among the school children.

\begin{tabular}{|c|c|c|c|}
\hline Intestinal parasites & Male 250(52.08) & Female 230(47.92) & Total 480 \\
\hline A lumbricoidies (\%) & $50(20.00)$ & $49(21.30)$ & 99 \\
\hline T tricuria (\%) & $6(2.40)$ & $10(4.35)$ & 16 \\
\hline Hookworm (\%) & $10(4.00)$ & $15(6.52)$ & 25 \\
\hline H.nana (\%) & $3(1.20)$ & $8(3.48)$ & 11 \\
\hline E.vermicularis(\%) & $4(1.60)$ & $4(17.39)$ & 8 \\
\hline Taenia (\%) & $15(6.00)$ & $18(7.82)$ & 33 \\
\hline E.histo/disp (\%) & $39(15.60)$ & $36(15.65$ & 75 \\
\hline G.lamblia(\%) & $36(14.4)$ & $36(15.65)$ & 72 \\
\hline Total & $\mathbf{1 6 3 ( 4 8 . 0 8 )}$ & $\mathbf{1 7 6}(\mathbf{5 1 . 2 9})$ & $\mathbf{3 3 9}$ \\
\hline
\end{tabular}

Table 3 Social and demographic factors of school children.

\begin{tabular}{|c|c|c|c|}
\hline Variable & Frequency & Prevalence (\%) & P value \\
\hline \multicolumn{4}{|l|}{ Sex } \\
\hline Male & 250 & 48.81 & 0.289 \\
\hline Female & 230 & 51.19 & \\
\hline \multicolumn{4}{|c|}{ No of people in the family } \\
\hline 6-Apr & 306 & 50.65 & \\
\hline 9-Jul & 127 & 48.81 & 0 \\
\hline$>9$ & 47 & 74.47 & \\
\hline \multicolumn{4}{|c|}{ Parent occupation } \\
\hline Farmer & 296 & 58.12 & \\
\hline Trader & 35 & 51.42 & 0 \\
\hline Civil servant & 71 & 33.8 & \\
\hline Other & 78 & 48.72 & \\
\hline \multicolumn{4}{|c|}{ Source of water } \\
\hline Borehole & 379 & 49.34 & 0 \\
\hline Others sources & 101 & 64.35 & \\
\hline \multicolumn{4}{|c|}{ Previous treatment } \\
\hline De-wormed & 172 & 45.34 & 0.01 \\
\hline Not de-wormed & 308 & 56.49 & \\
\hline \multicolumn{4}{|l|}{$\begin{array}{l}\text { Refugee camp } \\
\text { during flood }\end{array}$} \\
\hline Stayed at camp & 106 & 47.17 & 0 \\
\hline Off camp & 374 & 54.01 & \\
\hline \multicolumn{4}{|c|}{ Defecation site } \\
\hline Bush & 128 & 49.21 & \\
\hline Toilet & 352 & 53.69 & 0 \\
\hline \multicolumn{4}{|c|}{ Behavioral pattern } \\
\hline Bite finger nails & 314 & 50 & \\
\hline $\begin{array}{l}\text { Does not Bite } \\
\text { finger nails }\end{array}$ & 166 & 57.23 & 0.891 \\
\hline Walk bare foot & 237 & 54.43 & \\
\hline $\begin{array}{l}\text { Does not walk } \\
\text { bare foot }\end{array}$ & 243 & 50.62 & 0.891 \\
\hline \multicolumn{4}{|l|}{ Geophilia } \\
\hline Yes & 189 & 53.97 & 0 \\
\hline No & 291 & 51.55 & \\
\hline
\end{tabular}

\section{Stool Sample Examination}

\section{Macroscopic examination}

All specimen were examined to detect the presence of adult worms, or segment, the consistency, colour, presence of mucus and blood were also noted. Ethyl acetate concentration technique as described by Cheesbrough [16] was used to examine the stool for the presence of larvae, cysts or ova of parasites. Using a stick, about $1 \mathrm{~g}$ from each of the faecal specimen was emulsified in 4 $\mathrm{ml}$ of $10 \%$ formol water. Another $3 \mathrm{ml}$ of $10 \%$ formal water was added. The emulsified faeces were sieved into a beaker. The suspension was later transferred into a glass centrifuge tube and about $4 \mathrm{ml}$ of ethyl acetate was added. The tube was stoppered and shaken vigorously for 1 munite and then centrifuged at 3,000 rpm for 1 munite. The layer of faecal debris was loosened from side of the tube using an applicator stick and the supernatant poured away. The deposit was re-suspended by tapping the bottom of the tube with finger. The deposit was transferred to a slide using a Pasteur pipette. The slide was covered with

Table 4 Prevalence of malaria parasite among school children from different towns visited.

\begin{tabular}{|c|c|c|c|c|}
\hline $\begin{array}{c}\text { School } \\
\text { location }\end{array}$ & No examined & $\begin{array}{c}\text { No Infected } \\
(\%)\end{array}$ & $\begin{array}{c}\text { Infected } \\
\text { male (\%) }\end{array}$ & $\begin{array}{c}\text { Infected } \\
\text { female (\%) }\end{array}$ \\
\hline $\begin{array}{c}\text { Odekpe } \\
\text { Ohita }\end{array}$ & 64 & $56(87.5)$ & $37(57.81)$ & $19(29.68)$ \\
\hline Ossomala & 64 & $29(90.63)$ & $16(50.0)$ & $13(40.63)$ \\
\hline Akiliozizo & 64 & $58(90.63)$ & $26(40.63)$ & $32(50.0)$ \\
\hline Umunankwo & 32 & $29(90.63)$ & $14(43.75)$ & $15(46.88)$ \\
\hline Ogbakuba & 64 & $58(90.63)$ & $30(46.88)$ & $28(43.75)$ \\
\hline Okpoko & 64 & $48(75.0)$ & $19(29.69)$ & $29(45.31)$ \\
\hline Ochuche & 32 & $23(71.88)$ & $14(43.75)$ & $9(28.13)$ \\
\hline Amiyi & 64 & $55(85.94)$ & $31(48.44)$ & $24(37.5)$ \\
\hline Grand Total & 480 & $\mathbf{4 1 5 ( 8 6 . 4 6 )}$ & $\mathbf{2 2 0 ( 4 5 . 8 3 )}$ & $\mathbf{1 9 5}(40.63)$ \\
\hline
\end{tabular}

Table 5 The prevalence of malaria parasites, intestinal parasites and anaemia on school children in ogbaru lga by age range.

\begin{tabular}{|c|c|c|c|c|}
\hline Age range & $\begin{array}{l}\text { No. of } \\
\text { children } \\
\text { tested (\%) }\end{array}$ & $\begin{array}{l}\text { Intestinal } \\
\text { parasites (\%) }\end{array}$ & Anaemia (\%) & $\begin{array}{l}\text { Malaria } \\
\text { parasites (\%) }\end{array}$ \\
\hline 6-9 (YEARS) & $118(23.96)$ & $62(52.54)$ & $66(55.93)$ & 106(89.83) \\
\hline $\begin{array}{l}10-13 \\
\text { (YEARS) }\end{array}$ & $209(43.96)$ & $118(56.45)$ & $119(57.77)$ & $178(85.17)$ \\
\hline$>13$ (YEARS) & $153(32.08)$ & $75(49.02)$ & $80(52.29)$ & $131(85.62)$ \\
\hline TOTAL & $480(100.0)$ & $252(52.50)$ & $265(55.21)$ & $415(86.46)$ \\
\hline
\end{tabular}

Table 6 PCV and hb of children lower than the accepted reference value from various towns in ogbaru lga.

\begin{tabular}{|c|c|c|c|}
\hline School location & No. of children & PCV $(\%)$ & HB(g/dl) \\
\hline ODEKPE & 64 & $38(59.38)$ & $35(54.69)$ \\
\hline OHITA & 32 & $17(53.13)$ & $15(46.88)$ \\
\hline OSSOMALA & 64 & $36(56.25)$ & $32(50)$ \\
\hline AKILIOZIZO & 64 & $44(68.75)$ & $34(53.13)$ \\
\hline UMUNAKWO & 32 & $21(65.63)$ & $17(53.13)$ \\
\hline OGBAKUBA & 64 & $33(51.56)$ & $31(48.44)$ \\
\hline OKPOKO & 64 & $43(67.19)$ & $40(62.5)$ \\
\hline OCHUCHE & 32 & $22(68.75)$ & $18(56.25)$ \\
\hline AMIYI & 64 & $55(85.94)$ & $43(67.19)$ \\
\hline GRAND TOTAL & 480 & $309(64.38)$ & $265(55.21)$ \\
\hline
\end{tabular}

Reference value HB-11-16g/dl PVC 34-35\% 
Table 7 Effects of malaria parasitaemia on haemoglobin concentration and packed cell volume.

\begin{tabular}{|c|c|c|c|c|c|}
\hline $\begin{array}{c}\text { Malaria parasite } \\
\text { Level of parasitemia (+) }\end{array}$ & $\begin{array}{c}\text { No of children with } \\
\text { anaemia }\end{array}$ & $\begin{array}{c}\text { Mean } \pm \text { std } \\
\text { hb (g/dl) }\end{array}$ & p-value & $\begin{array}{c}\text { mean } \pm \text { std } \\
\text { pcv (\%) }\end{array}$ & p-value \\
\hline Level of parasitemia (++) & 93 & $9.95 \pm 0.76$ & 0.156 & $30.03 \pm 2.54$ & 0.017 \\
\hline \multicolumn{6}{|l|}{ No parasite seen } \\
\hline Total & 265 & $10.02 \pm 0.73$ & & $30.50 \pm 2.63$ & \\
\hline
\end{tabular}

a cover slip and examined under $x 10$ and $x 40$ objectives of the microscope. The ova/larvae of parasites were identified with reference to Atlas of Parasitology [17].

\section{Malaria parasite test}

Thick and thin blood smears were prepared and stained with giemsa stain and examined according to the procedure described by Cheesbrough [16].

\section{Haematological test}

Estimation of Packed cell volume (PCV) using haematocrit packed cell volume capillary method.

\section{Estimation of Haemoglobin Concentra-}

\section{tion by Cyanmethaemoglobin Method}

\section{Culture media}

CHROMagar liquid ECC, KF Streptococcus Agar and Reinforced Clostridium agar were prepared according to manufacturers' instruction.

\section{Culture}

KF Streptococcus agar was prepared based on formulation described by Kennor et al. [18]. The filtered sample on the membrane filter was transferred directly on the agar medium avoiding the formation of bubbles. The plates were inverted and incubated at $37^{\circ} \mathrm{C}$ for 48 hours. After 48 hours the red and pink colonies were counted and reported as faecal streptococci per $100 \mathrm{ml}$. To count the spores of sulphite-reducing Clostridia, the volume $(100 \mathrm{ml})$ of the water Sample was heated to $60 \pm$ ${ }^{\circ} \mathrm{C}$ and the whole volume maintained at this temperature for 15 minutes. Cooked meat medium were prepared according to manufactures instruction and the samples were inoculated into the medium for enrichment and incubated for 24 hours at $37^{\circ} \mathrm{C}$. Prior to filtration, reinforced clostridium differential agar was prepared and allowed to solidify. The samples were filtered and the filter membrane placed on the Petri dishes containing the medium and incubated at $37^{\circ} \mathrm{C}$ in an anaerobic jar containing gas-pak for 24 hours [19].

After incubation, all black or grey colonies were counted an expressed as number of colonies per $100 \mathrm{ml}$.

The colonies were sub-cultured on blood agar and incubated anaerobically for 24 hours according to method described by
Chessbrough [16]. The colonies showed marked haemolysis on blood agar after 24 hours.

Gram stain as described by Chessbrough [16] and spore staining using Schaeffer-Fulton Method [20] was carried out to identify the organism. Gram-positive organisms-purple, Gram-negative organisms-pink. Organism was large gram positive rods.

\section{Statistical Analysis}

The data collected were analysed using the statistical package for the social sciences-SPSS software version 16.0, ANOVA, ttest and Frequency distribution. Level of significance was set at $95 \%$ confidence interval, $\mathrm{p}<0.05$ was considered statistically significant.

\section{Discussion}

In this study, a high prevalence of intestinal parasites (52.50\%) was obtained. The children were infected with at least one species of these parasite; Ascaris lumbricoides, Entamoeba histolytica/ dispar, Giardia Lamblia, Taenia spp, Hook worm, Trichuris trichura, Enterobius vermicularis Hymenolepis nana. This prevalence is comparable with the rate reported in similar studies in Nigeria by Banke et al. [21] 54.13\%, Awolaju and Morenikeji [22] 48.4\%. However it is above the rate of $25.8 \%$ recorded by Akingbade et al. [23] among children with diarrhea in Abeokuta, Ogun State, Odu et al. [24] recorded $15.7 \%$ prevalence among primary school children in Rivers State. The higher prevalence and highest occurring intestinal parasite reported for Ascaris lumbricoides (29.20\%) in this study is lower than that of Akingbade et al. [23] $54.8 \%$, Odu et al. [24] 57.4\%, Omorodion et al. [25] $47.7 \%$ and $25 \%$ in Delta and Edo respectively. Hymenolepis nana (2.35\%) was the least occurring intestinal parasite. This is in agreement with the report of Emmy-Egbe et al. [26] with prevalence of $2.6 \%$. Intestinal parasitic infections are mainly acquired through faecal-oral route. High prevalence of intestinal parasite had been attributed to poor environmental conditions; shortage of good water supply, indiscriminate defecation and poor personal hygiene [26] which was also observed in this study and most of the children have never been dewormed. Entamoeba histolytica was the second most prevalent parasite amongst the children (22.1\%). Banke et al. [21] observed a prevalence of $7.06 \%$, Akingbade et al. [23] 19.4\%. Infection of human by $E$. histolytica commonly results in amoebiasis [27]. E. histolytica is indicator organism of faecal contamination of food or water and are frequently present in unhygiencally prepared foods and can lead to outbreaks of ameobiasis. The higher prevalence and incidence of Entaemoeba histolytica and Giardia lamblia are a reflection 
of the poor environmental sanitation and poor personal hygiene and unclean habits practiced by these children. Ignorance and illiteracy of the parents can also be attributed to these infections due to their lack of information on the mode of transmission and symptoms of intestinal parasite infection. Survey in Nigeria, by Okonko et al. [27] indicated that intestinal parasitic infections such as amoebiasis are growing problem in the country.

Most of the pupils especially those from primary schools in Odekpe, okpoko and Ossomala had mixed infection of Ascaris lumbricoides, Entamoeba histolytica/dispar, Giardia Lamblia or Hookworm. Multiple parasitisms have also been reported by Chukwuma et al. [28].

Parents occupational prevalence showed that infection rate was highest among the children whose parents were farmers $(58.12 \%)$, followed by the pupils whose parents where traders (51.42\%) while the pupils whose parents where civil servants showed the least prevalence $(33.80 \%)$ of infection with intestinal parasites. Difference in parents occupation prevalence was found to be statistically significant $(p<0.05)$.

Afzal and Sultan [29] reported a malaria prevalence of $75 \%$ in a flood affected area of Muzaffargarh District, Southern Punjab, Pakistan. Children in the rural area are less protected and are more prone to mosquito bite [30]. Brown [31] stated that in hyperendemic areas, the malaria is mild and asymptomatic in older children. Age and nutritional status of the host might represent natural or acquired resistance and can play a role in the severity of the disease produced [30].

\section{References}

1 Biswas R, Pal D, Mukhopadhyay SP (1999) A community based study on health impact of flood in a vulnerable district of West Bengal. Indian Journal of Public Health 43: 89-90.

2 Vollaard AM, Ali S, van Asten HA (2004) Risk factors for typhoid and paratyphoid fever in Jakarta, Indonesia. Journal of AMA 291: 26072615.

3 World Health Organization (2001) Burden of Diseases in DisabilityAdjusted Life Years (DALYs) by Cause, Sex and Mortality Stratum in WHO Regions. WHO, Geneva 41: 82-94.

4 Bethony J, Brooker S, Albonico M, Geiger S, Loukas A (2006) Soiltransmitted helminth infections: ascaridiasis, trichuriasis and hookworm. The Lancet 367: 1521-1532.

5 World Health Organization (2005) Deworming for health and development. Reports on the third global meeting of the partners for parasite control. Geneva 62: 223-265.

6 World Health Organization (2007) Partners for parasite control: geographical distribution and useful facts and stats. The Lancet 367: 1521-1532.

7 Nwosu ABC (1981) The Community ecology of soil transmitted helminth infections of human in a hyperendemic area of southern Nigeria. Annals of Tropical Medicine and Parasitology. 75: 197-203.

8 Brooker S, Clements A, Bundy DA (2006) Global epidemiology, ecology and control of soil-transmitted helminth infections.
From this study, most of the children were anaemic, therefore anaemia is of public health importance in Ogbaru LGA especially among the school children. The rate $(55.21 \%)$ recorded in this study is higher than the prevalence rate (38.6\%) recorded in Edo state by Osazuwa and Oguntade [32]. The highest prevalence of anaemia (57.77\%) was seen within age 10-13 followed by age 6-9 years $(55.93 \%)$ and the least in age $14-17$ years $(52.29 \%)$.

Poor nutrition [32], parasitic infections [33] and other factors have also been noted to increase the incidence of anaemia.

The effect of malaria parasitaemia on anaemia using the mean and standard deviation of $\mathrm{Hb}$ and PCV of the children with malaria parasite showed no significant difference between malaria parasitaemia and $\mathrm{Hb}$ concentration $(\mathrm{p}>0.05)$, however there was a significant difference between malaria parasitaemia and PCV $(p<0.05)$. Okafor et al. [34] and Cheesbrough [16] reported that anaemia as the commonest complication of malaria among 1-5 age groups. This study shows that anaemia found in some of the children could be due to other causes other than malaria.

\section{Conclusion}

The prevalence rate of intestinal parasite, malaria and anaemia in this study indicates that they are important public health problems in Ogbaru Local Government Area. There should be collective effort engineered towards prevention from infection and treatment of already established cases.

Advanced Parasitology 62: 223-265.

9 Dada Adegbola HO, Oluwatoba AO, Falade CO (2005) Prevalence of multiple intestinal helminths among children in rural community. African Journal for Medical Science 34: 263-367.

10 Ekejindu IM, Ekechukwu AC, Ezeagwuana DA (2005) Prevalence of parasitic oocystc and ova on Nigerian currency (Naira). Journal of Biomedical Investigation 3: 16-20.

11 World Health Organization (2002) The world health report: 2002: reducing risk, promoting healthy life Geneva 34: 26-36.

12 Koukounari A, Estambale, BB, Njagi JK, Cundill B, Ajanga A, et al. (2008) Relationships between anaemia and parasitic infections in Kenyan schoolchildren: a Bayesian hierarchical modeling approach. International Journal of Parasitology 38: 1663-1671.

13 Mahgoub HM, Mohamed AA, Magzoub M, Gasim GI, Eldein WN (2009) Schistosoma mansoni infection as a predictor of severe anaemia in schoolchildren in eastern Sudan. Journal of Helminthology 28: 1-4.

14 Bouyou-Akotet MK, Dzeing-Ella A, Kendjo Etoughe D, Ngoungou EB, Planche T, et al. (2009) Impact of Plasmodium falciparum infection on the frequency of moderate to severe anaemia in children below 10 years of age in Gabon. Malaria Journal 8: 1475-2875.

15 Friedman JF, Kanzaria HK, McGarvey ST (2005) Human schistosomiasis and anaemia: the relationship and potential mechanism. Trends in Parasitology 21: 386-392.

16 Cheesebrough M (2010) District Laboratory practice in tropical countries. Part 2. CambridgeUniversity Press 22: 156. 
17 Cheesbrough M (2000) District Laboratory practice in tropical countries Cambridge University press 22: 209-215.

18 Kennor GA, Clark HF, Kabler PW (1961) Journal for Applied Microbiology 9: 15-20.

19 Environmental Agency (2010) Microbiology of drinking water. Methods for Isolation and enumeration of sulphite reducing Clostridia and Clostridium perfringens by membrane filtration. UK 7-19.

20 Banke ROK, Omudu EA, Ikenwa DA, Feese IJ (2006) Prevalence of Gastro-intestinal Parasites in Relation to Availability of Sanitary Facilities Among Schooling Children in Makurdi, Nigeria. Animal Research International 3: 489-493.

21 Awolaju BA, Morenikeji OA (2009) Prevalence and intensity of intestinal parasites in five communitiesin south-west Nigeria. African Journal of Biotechnology 8: 4542-4546.

22 Akingbade OA, Akinjinmi AA, Ezechukwu US, Okerentugba PO, Okonko IO (2013). Prevalence of Intestinal Parasites among Children with Diarrhea in Abeokuta, Ogun State, Nigeria Researcher 5: 66-73.

23 Odu NN, Elechi VI, Okonko IO (2013) Prevalence of Intestinal Helminthes Infection among Primary School Children in Urban and Semi-Urban Areas in Port Harcourt, Rivers State, Nigeria. World Rural Observations 5: 52-61.

24 Omorodion AO, GoddeyN OP, Clement IC, Ogbeneovo UD, Oijiangbe AA (2012) Distribution of intestinal parasites among school age children in Delta and Edo States of Nigeria. PUJ 5: 121-126.

25 Emmy-Egbe IO, Ekwesianya EO, Ukaga CN, Eneanya Cl, Ajaero CMU (2012) Prevalence of Intestinal Helminthes in Students of Ihiala Local Government Area OF Anambra State. Journal of Applied Technology in Environmental Sanitation 2: 23-30.
26 Okonko IO, Soleye FA, Amusan TA, Mejeha OK, Babalola ET, et al. (2009) Detection and Prevalence Intestinal Parasites In Patients In Abeokuta, South-Western, Nigeria. World Applied Science Journal. 7: 1183-1187.

27 Chukwuma MC, Ekejindu IM, Agbakoba NR, Ezeagwuna DA, Anaghalu IC, et al. (2009) the prevalence and risk factors of geohelminth infections among primary school children in Ebenebe Town, Anambra State, Nigeria. Middle - East Journal for Science Research 4: 211-215.

28 Afzal MF, Sultan MA (2013) Experience of malaria in children of a flood affected area: a field hospital study. Eastern Mediterranean Health Journal 19: 613-616.

29 Nwaorgu OC, Orajaka BN (2011) Prevalence of Malaria among Children 1 - 10 Years Old in Communities in Awka North Local Government Area, Anambra State South East Nigeria. International Multidisciplinary Journal, Ethiopia 22: 264-281.

30 Brown $\mathrm{H}$ (2005) Treating the injured and burying the dead. Lancet 365: 204-205.

31 Osazuwa F, Oguntade MA (2010) Contribution of malnutrition and malaria to anemia in children in rural communities of Edo state, Nigeria. North American Journal of Medical Sciences 2: 532-536.

32 Carrilho GF, Da Costa GM, Olivi malta J, Vicentini V, Da Costa GM, et al. (2011) Anemia in patients with intestinal parasitic infection. Parasitology 70: 206-211.

33 Durugbo EU, Kajero AO, Omoregie El, Oyejide NE (2013) A survey of outdoor and indoor airborne fungal spora in the Redemption City, Ogun State, south-western Nigeria. Aerobiologia 29: 201-216.

34 Okafor HU, Nwaiwu K (2001) Anaemia of Persistent malarial parasitemia in Nigerian children. Journal of Tropical Pediatricans 47: 271-275. 